УДК 343.415

DOI https://doi.org/10.32837/pyuv.v0i2(27).211

\author{
M. A. Грига \\ кандидат юридичних наук, \\ старший науковий співробітник наукової лабораторії \\ з проблем протидї злочинності \\ Навчально-наукового інституту № 1 \\ Національної академії внутрішніх справ \\ С. В. Григорова \\ здобувач кафедри досудового розслідування \\ Навчально-наукового інституту № 1 \\ Національної академії внутрішніх справ
}

\title{
СТАНОВЛЕННЯ ЗАКОНОДАВЧОГО ЗАКРІПЛЕННЯ КРИМІНАЛЬНОЇ ВІДПОВІДАЛЬНОСТІ ЗА ПІДКУП ВИБОРЦЯ
}

Легітимні демократичні вибори як втілення однієї з форм безпосередньої демократії є підгрунтям політичної стабілізації, без якої неможливий сталий економічний та соціальний розвиток країни. Крім того, упровадження демократичних принципів формування органів державної влади й органів місцевого самоврядування є однією з обов'язкових умов подальшої інтеграції України до Європейського Союзу. Виборчі перегони 2019 р. продемонстрували, що в цілому у нашій державі створені відповідні умови для дотримання законності під час виборів: на законодавчому рівні закріплений комплекс нормативно-правових актів, які відповідають міжнародним стандартам гарантування конституційних виборчих прав громадян, забезпечена активна участь у виборчому процесі міжнародних спостерігачів та представників громадських організацій тощо. Однак під час проведення цьогорічних виборчих перегонів фіксувалась значна кількість порушень, серед яких підкуп виборців у деяких регіонах набував масового характеру. Даний факт, крім іншого, зумовлений неоднозначним ставленням громадян до цього негативного явища, більшість яких згідно з даними численних соціологічних опитувань не сприймає такі порушення як злочинні дії. Отже, встановлення адекватної за ступенем небезпечності даного виду злочинних проявів кримінальної відповідальності набуває наразі особливої актуальності, що й зумовило вибір теми статті.

Проблеми протидії злочинам проти виборчих прав громадян у контексті дослідження їх кримінально-правової кваліфікації, особливостей розслідування, а також кримінологічної характеристики та профілактики вивчали Л.В. Гудзь, В.М. Колесниченко, А.М. Колодій, С.В. Красноголовець, О.В. Кубарєва, О.В. Лавринович, С.Я. Лихова, М.В. Мазур, Л.П. Медіна, М.І. Мельник, С.А. Мозоль, М.О. Мягков, Н.М. Парасюк, М.Л. Ставнійчук, Ю.М. Тодика, М.I. Хавронюк та інші. Проте окремо питання становлення законодавчого закріплення кримінальної відповідальності за підкуп виборця у роботах зазначених вчених не було висвітлене, а численні публікації на відповідну тему, що часто трапляються в засобах масової інформації, мають переважно публіцистичний характер. Отже, метою статті є дослідження становлення кримінальної відповідальності за підкуп виборців та аналіз сучасного стану її законодавчого закріплення.

Через історичні умови становлення у вітчизняному праві кримінальної відповідальності за виборчі правопорушення нерозривно пов'язане iз розвитком законодавства Російської імперії. На думку М.В. Мазура, один з перших прототипів норми про відповідальність за порушення виборчих прав містився у Іменному указі Катерини II від 14.12.1766 р. «Про створення в Москві комісії для складання нового Уложення та про вибори до неї депутатів», де під «острахом Нашого неминучого гніву» заборонялося утискувати будь-кого на виборах і брати для цього хабарі [1, с. 539].

Досліджуючи проблеми історії розвитку законодавчого закріплення кримінальної відповідальності за злочини проти конституційних прав і свобод людини і громадянина, А.М. Красіков вказує на Уложення про покарання кримінальні та виправні 1845 р., зокрема на розділ IX «O преступлениях и проступках против законов о состоянии», глава четверта якого («Про порушення правил для виборів й інших зібрань дворянських, міських і сільських") передбачала відповідальність осіб, які під час виборів через підкуп, подарунки, обіцянки або погрози схиляли іншу особу до подання голосу на їхню користь або на користь чи проти іншої особи [2, с. 5]. На нашу думку, саме дана норма є прообразом норми кримінального законодавства, що закріплювала відповідальність за підкуп виборців. Звертає на себе увагу також розділ, де містилася зазначена норма згаданих 
Уложень, що свідчить про те, що вже тоді порушення виборчих прав громадян розглядались як зазіхання на інтереси всього суспільства в цілому, а не на права окремої особи.

Наступний етап становлення кримінальної відповідальності за порушення виборчих прав припадає на часи радянського періоду. Однак зазначимо, що, попри те, що норми покарань за окремі порушення в галузі реалізації виборчих прав містилися і у КК РРФСР 1922 р. (ст. 104 передбачала покарання у вигляді примусових робіт на строк не менше трьох місяців за участь у виборах до рад особи, яка не мала на те законного права), і у КК РРСФР 1926 р. (ст. 91-1 встановлювала відповідальність у вигляді примусових робіт на строк до шести місяців або штрафу до п'ятисот карбованців за перешкоджання з боку наймача в сільській місцевості здійсненню особами найманої праці виборчих прав), відповідальність саме за підкуп виборців у даних нормах (а також і у нормах КК УСРР) передбачена не була.

I лише 09.07.1937 p. постановою ЦВК СРСР було затверджене Положення про вибори до Верховної Ради Союзу РСР, яке містило дві норми кримінально-правового характеру, у одній з яких (ст. 111) зазначалося: «Будь-яка особа, яка шляхом насильства, обману, погроз чи підкупу перешкоджатиме громадянину СРСР у здійсненні його права обирати та бути обраним до Верховної Ради СРСР, карається позбавленням волі на строк до двох років» .

Аналогічну норму було зафіксовано і у Положенні про вибори до Верховної Ради УРСР, затвердженому Постановою п'ятої сесії ЦВК УРСР від 21.02.1938 р. Цей же склад злочину відтворювався і у Кримінальному кодексі УРСР. Зокрема, у Постанові ЦВК і РНК УРСР від 02.12.1937 p. «Про зміну ст. 85-1 Кримінального Кодексу УРСР i про доповнення цього Кодексу статтею 108-1» ст. 85-1 була викладена у такій редакції: «За перешкоджання шляхом насильства, обману, погроз або підкупу громадянину Союзу РСР у здійсненні його права обирати і бути обраним в Ради народних депутатів трудящих - позбавлення волі на строк до двох років» [3, с. 28].

У Положенні про вибори до Верховної Ради СРСР, затвердженому Указом Президії Верховної Ради СРСР від 11 жовтня 1945 р., також був передбачений аналогічний склад злочину.

Проект Кримінального кодексу СРСР 1955 року включав три статті, які передбачали кримінальну відповідальність за порушення виборчих прав, - «Перешкоджання здійсненню виборчого права» (ст. 103), «Підміна виборчих документів або неправильний підрахунок голосів" (ст. 104) та «Порушення таємниці голосування» (ст. 105). Примітно, що у ідентичному вигляді зазначені кримінально-правові норми зберегли- ся і у прийнятих пізніше кримінальних законах СРСР і УРСР. Зокрема, Кримінальний кодекс УРCP 1960 р. містив главу IV Особливої частини «Злочини проти політичних і трудових прав громадян», у якій і містилися три вищезазначені склади злочинів у ст. ст. 127-129. Про підкуп як один зі способів перешкоджання здійсненню виборчого права йшлося у ст. 127 , яка передбачала за даний злочин санкцію у вигляді позбавлення волі на строк до одного року або виправні роботи на той самий термін [4].

У КК України 2001 року кримінальна відповідальність за підкуп виборців була передбачена в межах ч. 1 ст. 157 «Перешкоджання здійсненню виборчого права», у диспозиції якої підкуп зазначався як один зі способів вчинення злочину. Водночас у ч. 1 ст. 160 даного Кодексу встановлювалась кримінальна відповідальність за підкуп як спосіб перешкоджання вільному здійсненню громадянином права брати або не брати участь у референдумі, вести агітацію до дня проведення референдуму.

Виявлені порушення під час виборчої кампанії 2014 року продемонстрували недосконалість законодавчого урегулювання кримінальної відповідальності, у тому числі й за підкуп виборців. Законом України «Про внесення змін до Кримінального кодексу України щодо посилення відповідальності за порушення виборчих прав громадян» від 14 жовтня 2014 року № 1703-VII [5] до відповідних норм Кодексу було внесено зміни. Зокрема, у ч. 1 ст. 157 слово «підкупом» виключалося, натомість ст. 160 викладалася у повністю оновленій редакції. Якщо первинно дана норма стосувалася виключно порушень законодавства про референдум, то відтоді зазначена стаття стала називатися «Підкуп виборця, учасника референдуму», тобто фактично кримінальну відповідальність за підкуп виборців було встановлено в межах окремого складу злочину. Крім того, кримінальна відповідальність поширювалася не лише на тих, хто підкуповує виборців, а й самих виборців, які отримують незаконну вигоду від голосування.

Необхідно зазначити, що внесені законодавцем зміни викликали неоднозначну оцінку як науковців, так і громадськості. Зокрема, на сайті громадянської мережі «Опора», активісти якої неодноразово фіксували численні порушення під час виборчого процесу, крім схвальної реакції щодо посилення кримінальної відповідальності за подібні порушення, наголошувалося на тому, що «рішення Парламенту було прийняте вже на етапі завершення агітаційної кампанії, що дозволяє кандидатам уникнути відповідальності за вже здійсненні правопорушення. "Опора» наполягає на невідкладному підписанні Президентом України змін до Кримінального Кодексу України із метою попередження порушень в останні дні пе- 
редвиборчої агітації, у день голосування, під час підрахунку голосів та встановлення підсумків голосування в округах» [6].

Водночас запроваджені зміни викликали деякі зауваження і у фахівців у галузі кримінального права. Так, Н.М. Парасюк зазначав, що викладення ст. 160 КК України у новій редакції, яка повністю змінила зміст кримінально-правової норми, видається сумнівним. Учений також зауважив, що здійснення передвиборної агітації (агітації референдуму) шляхом надання підприємствам, установам, організаціям неправомірної вигоди або надання безоплатно товарів, робіт, послуг є доволі нетиповою формою підкупу. На думку Н.М. Парасюка, з погляду законодавчої техніки така стаття мала б бути виключена із тексту кримінального закону. КК України слід було б доповнити статтею 160-1 у внесеній Законом України від 14 жовтня 2014 року № 1703-VII редакції. Проте учений зазначає, що науковці неодноразово наголошували на доцільності декриміналізації порушення законодавства про референдум, оскільки первинна редакція ст. 160 КК України створювала колізію з іншими кримінально-правовими нормами.

Неоднозначним є ставлення науковця і до визначення дефініції неправомірної вигоди. По-перше, вона обмежується у предметному розумінні лише коштами чи іншим майном, перевагами, пільгами, послугами або нематеріальними активами. У класичному ж розумінні неправомірна вигода включає ще й «будь-які інші вигоди нематеріального чи негрошового характеру» (примітки до статей 354, 364-1 КК України). По-друге, законодавець установив для виборчої неправомірної вигоди розмір її криміналізації, а саме перевищення трьох відсотків розміру прожиткового мінімуму для працездатних осіб. На сьогодні, на думку вченого, ця сума не перевищує навіть розмір мінімальної заробітної плати, установленої Законом «Про Державний бюджет». Сумнівною видається дієвість цієї норми з огляду на можливість пропозиції виборцю за відмову від участі в голосуванні чи передання виборчого бюлетеня неправомірної вигоди саме у такому розмірі [7, с. 193].

Необхідно зазначити, що протягом останніх років внесення змін до кримінальних норм, які встановлюють кримінальну відповідальність за злочини проти виборчих прав громадян, набуло системного характеру. Ми пов'язуємо це з інтенсифікацією виборчих процесів у нашій державі, а також, з одного боку, з підвищеним суспільним запитом на проведення виборчих перегонів відповідного рівня, з іншого - з рефлексією на вже виявлені під час виборчого процесу порушення. Отже, як цілком справедливо зазначають науковці, норми виборчого законодавства традиційно зазнавали істотних змін практично під час кожних виборів в Україні [8, с. 7]. Крім негативних ви- словлювань науковців [9, с. 33], такі часті зміни виборчого законодавства суперечать рекомендаціям, закріпленим у нормах міжнародного права. Ідеться, зокрема, про Інтерпретативну декларацію про стабільність виборчого законодавства, прийняту Венеціанською комісією у 2005 році, у якій зазначається, що будь-яка реформа виборчого законодавства, яке має застосовуватися на виборах, повинна бути проведена достатньо завчасно, щоб бути дійсно застосовною під час виборчого процесу [10].

Наразі удосконалення законодавчого закріплення кримінальної відповідальності за підкуп виборців триває, що зумовлено виявленими під час минулих виборчих кампаній проблемними аспектами, які потребують вирішення. Зокрема, 3 цією метою Громадянською мережею "Опора» спільно з Міністерством внутрішніх справ України та Національною поліцією України був розроблений проект закону «Про внесення змін до деяких законодавчих актів України щодо посилення відповідальності за порушення виборчого законодавства». Робота над ним стартувала ще у 2016 році з регіональних обговорень результатів розслідування злочинів проти виборчих прав громадян, вчинених на чергових місцевих виборах 2015 року. Інклюзивний та комплексний характер процесу розробки цього законопроекту забезпечив включення до його положень обгрунтованих пропозицій слідчих, які безпосередньо працюють з виборчими правопорушеннями, спостерігачів від громадських організацій та інших суб'єктів виборчого процесу, науковців тощо [11].

Зазначений законопроект був презентований на засіданні Кабінету Міністрів України 11 квітня 2018 р., а 13 квітня був зареєстрований у Верховній Раді та отримав реєстраційний номер № 8270. Документ був розглянутий та підтриманий Комітетом Верховної Ради з питань законодавчого забезпечення правоохоронної діяльності, який у висновку рекомендував прийняти його за основу.

Пропонуємо коротко зупинитись на основних положеннях даного законопроекту в частині внесення змін до ст. 160 КК України.

По-перше, законопроектом уперше пропонувалося ввести санкцію у вигляді позбавлення волі строком до 2 років за отримання виборцем неправомірної вигоди, пов'язаної 3 реалізацією активного або пасивного виборчого права (ч. 1 ст. 160 КК України). Крім того, пропонується посилення відповідальності шляхом збільшення санкції у вигляді позбавлення волі до 6 років у ч.ч. 2 та 3 ст. 160 КК України. Крім суто профілактичної ролі, дані зміни мають на меті отримання правових підстав для затримання правопорушника та проведення відповідних процесуальних заходів. Як зазначається у висновку Комітету ВР України з питань законодавчого забезпечення 
правоохоронної діяльності, завдяки цим змінам правоохоронці отримають можливість здійснювати негласні слідчі дії та збирати належні докази для притягнення до відповідальності недобросовісних учасників передвиборчої боротьби [12].

По-друге, проект передбачає звільнення від кримінальної відповідальності осіб, які добровільно повідомили правоохоронні органи про вчинення злочинів щодо підкупу виборців та сприяли розслідуванню. Ця новація мотивує сприяти правоохоронцям громадян, яких під час виборів намагатимуться залучити до незаконної діяльності. Однак звільнення від кримінальної відповідальності не буде стосуватись організаторів підкупу виборців.

По-третє, відповідно до проекту запроваджується відповідальність за підкуп кандидата. Ця новела покликана запобігти використанню негативних виборчих технологій щодо висування так званих технічних кандидатів чи кандидатів-двійників.

Крім того, проект також передбачає введення кримінальної відповідальності за здійснення передвиборної агітації, яка супроводжується наданням неправомірної вигоди виборцям на відміну від чинного Кримінального кодексу, у якому така відповідальність встановлена лише за надання неправомірної вигоди юридичним особам.

Зрештою, у проекті суттєво розширено зміст примітки до ст. 160 КК України щодо розуміння неправомірної вигоди, яка може незаконно надаватися виборцям. Зокрема, до такої неправомірної вигоди включено спиртні напої та продукти харчування, які масово роздаються на виборах в Україні з метою підкупу виборців.

Наразі робота над законопроектом триває. До нього вносяться зміни відповідно до висловлених Комітетом ВР України з питань законодавчого забезпечення правоохоронної діяльності зауважень.

Взагалі, на думку фахівців, можливості для підкупу та обсяги фальсифікацій під час проведення виборів значно збільшують суперечності та колізії у виборчому законодавстві. Зараз на часі здійснення цілісної та системної кодифікації національного виборчого законодавства на основі вже напрацьованих демократичних здобутків та принципів, закладених у Конституції України, тобто прийняття єдиного Виборчого Кодексу України. Окрім того, варто створити національний реєстр осіб, причетних до фальсифікацій та підкупу, з метою недопущення їх у майбутньому до участі в організації виборчого процесу [13]. Залишається лише додати, що реалізація вищезазначеного значною мірою сприятимеме ефективній протидії та розслідуванню підкупу виборців правоохоронними органами.

Таким чином, становлення законодавчого закріплення кримінальної відповідальності за підкуп виборців охоплює декілька таких етапів: дореволюційний (з кінця XIX ст. до 1917 р.), коли прообраз відповідної норми містився в Уложенні про покарання кримінальні та виправні 1845 р.; радянський (ст. 85-1 КК УРСР 1937 р., ст. 127 КК УРСР 1960 р.); сучасний, який включає два періоди - до 2014 р., коли підкуп виборця був передбачений як один зі способів учинення злочину (ч. 1 ст. 157 КК України 2001 р.), та після 2014 р., коли кримінальна відповідальність за даний злочин передбачалась окремою нормою КК України (ст. 160).

Наразі робота над удосконаленням законодавчого закріплення кримінальної відповідальності за підкуп виборця триває, що зумовлено встановленням невідповідності положень чинної кримінальної норми потребам правозастосовної практики в умовах значного поширення даного виду злочинів під час виборчих перегонів.

\section{Jimepamypa}

1. Мазур М.В. Злочини проти виборчих прав громадян: історико-правовий аспект. Форум права. 2011. № 2. C. 539-545. URL: http://www.nbuv.gov.ua/ e-journals/FP/2011-2/11mmvipa.pdf.

2. Красиков А.Н. Уголовно-правовая охрана политических, гражданских и иных конституционных прав и свобод человека и гражданина в России. Саратов : Издательство Саратовского университета, 2000. 104 с.

3. Медіна Л.П. Кримінально-правова характеристика злочинів проти виборчих прав громадян України (ст.ст. 157, 158, 159 КК України) : дис. ... канд. юрид. наук : 12.00 .08 . Київ, 2004. 226 с.

4. Уголовный кодекс Украинской ССР. Киев : Государственное издательство политической литературы УССР, 1963. С. 60.

5. Про внесення змін до Кримінального кодексу України щодо посилення відповідальності за порушення виборчих прав громадян : Закон України від 14 жовтня 2014 року № 1703-VII. URL: https://zakon. rada.gov.ua/laws/show/1703-18.

6. Звіт про підкуп виборців та застосування адміністративного ресурсу на позачергових виборах народних депутатів України. URL: https://www.oporaua.org/ report/vybory/parlamentski-vybory/pozachergovivybory-do-verkhovnoyi-radi-2014-roku/6691-pidkupvyborciv-ta-zastosuvannja-administratyvnogo-resursuna-pozachergovyh-vyborah-narodnyh-deputativukrajiny.

7. Парасюк Н.М., Парасюк В.М. Регламентація кримінальної відповідальності за виборчі та референдні злочини: стан законодавчих змін. Юридичний вісник. Вип. 2 (43). 2017. С. 188-198.

8. Тагієв С.Р., Мазур М.В., Мягков М.О. Порушення виборчого законодавства: проблеми судового оскарження та юридичної відповідальності : препринт. Луганськ : РВВ ЛДУВС, 2006. 208 с.

9. Богашева Н.В. Законодавче регулювання виборів в Україні: проблеми стабільності. Наукові записки Інституту законодавства Верховної Ради України. 2014. № 2. C. $32-38$.

10. Інтерпретативна декларація про стабільність виборчого законодавства від 15 грудня 2005 p. URL: https://pravo.studio/evropeyskoe-pravo/interpretativnadeklaratsiya-pro-stabilnist-63545.html.

11. Законопроект №8270 щодо відповідальності за виборчі злочини підтримали на комітеті та 
радили до прийняття у ВР. Сайт Громадянської мережі «Опора». URL: https://www.oporaua.org/ news / vybory/46591-zakonoproekt-8270-shchodovidpovidalnosti-za-vyborchi-zlochyny-pidtrymaly-nakomiteti-ta-radyly-do-pryiniattia-u-vr.

12. Висновок Комітету Верховної Ради України з питань законодавчого забезпечення правоохоронної діяльності щодо проекту закону про внесення змін до деяких законодавчих актів України щодо посилення відповідальності за порушення виборчого законодавства № 8270. URL: http://w1.c1.rada.gov.ua/pls/ zweb2/webproc4 1?pf3511 $=63864$.

13. Наход М.А., Хромова Ю.О. Деякі проблемні питання проведення якісних місцевих виборів за новим виборчим законом: науково-практичний аспект. Державне будівниитво. № 1/2015. C. 11. URL: http://nbuv.gov.ua/UJRN/DeBu_2015_1_6.

\section{Анотація}

Грига М. А., Григорова С. В. Становлення законодавчого закріплення кримінальної відповідальності за підкуп виборця. - Стаття.

У статті досліджено становлення підстав кримінальної відповідальності за вчинення підкупу виборців. Виокремлено три таких основних етапи становлення законодавчого закріплення кримінальної відповідальності за дані злочини: дореволюційний (з кінця XIX ст. до 1917 р.), коли прообраз відповідної норми містився в Уложенні про покарання кримінальні та виправні 1845 р.; радянський (ст. 85-1 КК УРСР 1937 р., ст. 127 КК УРСР 1960 р.); сучасний, який включає два періоди - до 2014 р., коли підкуп виборця був передбачений як один зі способів учинення злочину (ч. 1 ст. 157 КК України 2001 р.), та після 2014 р., коли кримінальна відповідальність за підкуп виборця передбачалась окремою нормою КК України (ст. 160).

Встановлено, що сучасний етап становлення законодавчого закріплення кримінальної відповідальності за підкуп виборця характеризується постійними змінами, що зумовлені підвищеним суспільним запитом на проведення виборчих перегонів відповідного рівня та реакцією на значне поширення даного виду злочинів під час виборчих перегонів. 3'ясовано, що такі зміни часто відбуваються напередодні чергових виборів, що суперечить рекомендаціям, закріпленим у нормах міжнародного права.

Проаналізовано проект закону «Про внесення змін до деяких законодавчих актів України щодо посилення відповідальності за порушення виборчого законодавства» № 8270 в частині положень, що стосуються ст. 160 КК України. Зроблено висновок про те, що законодавче закріплення кримінальної відповідальності за підкуп виборця потребує подальшого вдосконалення. Це зумовлено встановленням невідповідності положень чинної кримінальної норми потребам правозастосовної практики.

Ключові слова: злочин, вибори, підкуп виборця, кримінальний закон, кримінальна відповідальність.

\section{Summary}

Hryha M. A., Hryhorova Ye. V. Genesis of legislative formation of criminal responsibility for the bribery of a voter. - Article.

The article investigates the formation of grounds for criminal responsibility for committing bribery of voters. There are three main stages of the formation of the legislative fixation of criminal responsibility for the following crimes: pre-revolutionary (from the end of the 19th century to 1917), when the prototype of the relevant norm was contained in the Criminal and Correctional Penalty in 1845; Soviet (Art. 85-1 of the Criminal Code of the Ukrainian SSR in 1937, Art.127 of the Criminal Code of the Ukrainian SSR in 1960); modern, which includes two periods: until 2014, when voter bribery was envisaged as one of the ways of committing a crime under Part 1 of Art. 157 of the Criminal Code of Ukraine in 2001, and after 2014, when criminal liability for bribery of a voter was provided for by a separate rule of the Criminal Code of Ukraine (Art.160).

It is established that the current stage of legislative establishment of criminal responsibility for voter bribery is characterized by constant changes, which are conditioned by an increased public demand for high-level elections and a reaction to the widespread election crimes during electoral race. It has been found that such changes often occur on the eve of the next election, which is contrary to the recommendations laid down in international law.

The draft law "On Amendments to Certain Legislative Acts of Ukraine on Strengthening Responsibility for Violation of Election Law” № 8270 has been analyzed in the part of the provisions concerning Art. 160 of the Criminal Code of Ukraine. It is concluded that the legislative fixing of criminal liability for bribery of a voter needs further improvement, which is conditioned by establishing the inconsistency of the provisions of the current criminal norm with the needs of law enforcement practice.

Key words: crime, elections, voter bribery, criminal law, criminal responsibility. 